Haya: The Saudi Journal of Life Sciences

Abbreviated Key Title: Haya Saudi J Life Sci ISSN 2415-623X (Print) |ISSN 2415-6221 (Online) Scholars Middle East Publishers, Dubai, United Arab Emirates Journal homepage: http://scholarsmepub.com/haya/

Original Research Article

\title{
Studies on Utilization of Germinated Dried Powder of Barley for the Development of Lemon Ready to Serve Drink
}

Haseeb Haroon ${ }^{1}$, Ummul Buneen ${ }^{2}$, Yasmeen Bano ${ }^{3}$, Mehak Fatima ${ }^{4}$, Zeshan akram ${ }^{5}$, M. Subtain ${ }^{4}$, M. Sufyan Khalid ${ }^{2}$, M. Faizan Khurram ${ }^{2}$, H. M. Asmar Naeem ${ }^{2}$ and S. Naeem Sajid ${ }^{2 *}$

${ }^{1}$ University of Sargodha, Institute of Food Science and Technology, Pakistan

${ }^{2}$ University of Agriculture Faisalabad, Centre of Agricultural Biochemistry and Biotechnology, Pakistan

${ }^{3}$ University of Agriculture Sub Campus Burewala, Vehari, National Institute of food Science and Technology, Pakistan

${ }^{4}$ University of Agriculture Faisalabad, Institute of Food Science and Technology, Pakistan

${ }^{5}$ Faculty of Health Sciences, School of Public Health, Curtin University Bentley Campus Perth Western Australia

DOI: $10.36348 /$ sils.2019.v04i11.001

| Received: 19.12 .2019 | Accepted: 26.12.2019 | Published: 30.12 .2019

*Corresponding author: Syed Naeem Sajid

Abstract

Barley (Hordeum vulgare L.). Sprouting has been used to improve the nutritional value of grains. The main objective of this study was to analyze the Physical analysis (pH, Acidity, TSS, Sensory Attributes, Color, Flavor, Taste) analysis of Lemon Barley RTD. Fine powder of barley Haider-93 utilized with combination of Sprouted barley powder to develop Lemon (RTD).Sensory evaluation of product was done on nine point hedonic scales. The product was packed in PET bottles and was evaluated for 90 days storage. Data was evaluated statistically and were interpreted.

Keywords: Serve Drink, Barley, Sensory evaluation, Hordeum vulgare L.

Copyright @ 2019: This is an open-access article distributed under the terms of the Creative Commons Attribution license which permits unrestricted use, distribution, and reproduction in any medium for non-commercial use (NonCommercial, or CC-BY-NC) provided the original author and source are credited.

\section{INTRODUCTION}

Barley (Hordeum vulgare L) is fast growing cool season cereal crop. It is used for the extraction of malt in beverage industries. It is grown throughout the world in temperate climate from ancient times as a cereal grain.

\begin{tabular}{|l|l|}
\hline Scientific name & Hordeum vulgare L \\
\hline Common name & Gars (Afrikaans) \\
\hline Family & Gramineae \\
\hline Kingdom & Plantae - Plants \\
\hline Subkingdom & Tracheobionta - Vascular plants \\
\hline Super division & Spermatophyta - Seed plants \\
\hline Division & Magnoliophyta - Flowering plants \\
\hline Class & Liliopsida- Monocotyledons \\
\hline Subclass & Commelinidae \\
\hline Order & Cyperales \\
\hline Family & Poaceae - Grass family \\
\hline Genus & Hordeum \\
\hline Species & H. vulgare \\
\hline
\end{tabular}

\section{Barley Grain}

Barley grain is reproductive unit of plant. A barley grain can be divided into three components:

\section{- Husk \\ - Endosperm \\ - Embryo}

Ratio of every segment of barley grain is $7 \%$ to $13 \%$ husk, $70 \%$ to $80 \%$ endosperm and $2 \%$ to $5 \%$ fetus. Barley grain contains up to $97 \%$ starch, $8 \%-15 \%$ protein content on conclusive barley grain weight. Arabic, Chinese, Greek, Egyptians and Ethiopia before composing and late Asian Civilization called hordearii. Bread of revealing numerous extraordinary nourishment and stamina gave physical quality other harvests and grain had more significance in substance and power supply. Barley is an important cereal crop which belongs to grass family Triticeae. Wheat and rye are also the member of this family. The grains are classified into thirty-one categories and barley is one of them. Out of these thirty one categories about three fourths are persisting grasses, which bloom in summer and harvested and utilized in winter. Scientists evaluate that Barley grain encircled from one forebear plant, Hordeum spontaneum. Wheat and Barley grain are corelated with each other and sometime their flour is 
combined for making many nutritious products. $H$. vulgare is a diploid with two genome plans of chromosomes. It is self-pollinated crop and the chances of out crossing about $1-5 \%$ [1].

Its grain is most important and it attains $4^{\text {th }}$ or $5^{\text {th }}$ position in the world among cereals production. United States, is the largest user of barley, they used $65 \%$ as animal fodder and $30 \%$ for the production of malt and alcohol era (30 \%). In 1991, grain was used as food in European Union and besides in lower $(0.3 \%)$ in United States. In previous reports, in the middle of 1990'sits most prominent use in Morocco (61 \%), China (62\%), India (73\%), and Ethiopia (79 \%). Grain was generally used as a cereal grain food in nineteenth century. In Europe wheat, rye, oats and barley grain are mainly used as cereal grain for food contrary to rice. Its grains are used for controlling many diseases, it is best for diabetic patients. Its porridge is extensively used as a food [2].

The wheat, barley, corn, rice are grains that are extensively used as a food of the whole world. The Barley grain attains fourth position in world after maize, rice and wheat. Various European countries used barley instead of wheat in their daily life to keep their body healthy and sound. Its grain is also given to the poultry for the best nourishment of poultries. It is the best source of animal food despite the protein needs of animals. It also fulfills the amino acid and fiber demand of animals [3].

Its grain can germinate various kind of soil, for example, lighter soil (unfertile) or well beneficial earth (fertile) but it cannot be grown on water logged soil. The water logged soil is unable to transfer the nutrients to the plant as most of the nutrients leached due to excessive water. It can tolerate the Soil $\mathrm{pH}$ of 5-8. Its grain germinates in both dry and cool conditions and remains active [4].

\section{Available Products of Barley \\ Flakes (Flaked)}

The grains are used to make flakes. They are cooked and used as hot cereals as well as with the milk.

\section{Flour}

Flour is made from barley grain. But its flour contains low amount of gluten that's why it is not used for making of bread.

\section{Hulling}

The barley seeds are packed in a membrane called hull the whole grain is edible. Only outer inedible husk called the spikelet- is dislodged as it is not edible portion. Hull is rich in fiber. It substitute iron and trace minerals than pearl and four times than thiamin. Hull has ambrosial flavor which makes like ingredient in stew and stews.
Pasta

Pasta is one of pasta divergence available in market. Flower to some degree nutty-tasting pasta made from flour.

\section{Pearl Barley}

Barley grains were enumerated six times during milling to exhaustively remove their double outer husk and their bran layer. Milling curtails grain's cooking time. Pearl barley has a decrepit nutlike taste.

\section{Pot (Scotch)}

Pot is granulating just three times bran layer remains. It was supplemental to soups and stews. It is found in health food fountain.

\section{UN-hulled}

Whole grains in cohesive outer husk are crumb labor intensive to hull but adopted for making sprouts. Grown for brewer's malt is called malting and is branched into two general types:

\section{2-Row}

The barley is of two types two row barley and 6 row barley. The two row barley contains two rows of florets in one side.

\section{6-Row:}

While 6 row barley contains 3 florets in one side of spike and 6 florets in both sides. Barley grain can be germinated in many soil types including highly fertile or infertile (medium soils). It is heat and drought tolerant that property of this crop makes it a gainful plant for ranges. The barley is also the most salttolerant among cereal crops. It easily germinated at soil $\mathrm{pH}$ in the region of 5.0 and 8.3 [5].

In Pakistan, wheat is standard which is used as a cereal grain staple food. Its production is $23,864,000$ tons from 9,042 thousands ha but the demand was 25 million tons amid so it resulted creates a deficiency. There is not proper policy that supports the wheat production and feed the 180 million peoples at present. Barley grain would be an economical product in territories where water system was not easily accessible. The grain can be given more standard yields than wheat in both harsh and rain-bolstered territories. All around developed region of Barley grain in Pakistan is just 80,000 ha with production of 78,000 tons [6].

The grain has been used as foodstuff for human and animals since years. To get supreme nutrients cost effectively from the grains different techniques has been applied e.g. sprouting, fermentation, heat therapy etc. The era of using scattered its grains in poultry diet was increasing due to different reasons. For example sprouting was a selfexplanatory technique for the betterment of their nutritive value. A required nutritional changes may be preferred during sprouting that were because of 
breakdown of complex mixes into a farthest straightforward as $\mathrm{ABC}$ shape, change into required fixings and breakdown of undesirable constituents [7].

Sprouting of grains compassionate the enzyme activity, increased total protein and changes in amino acid profile, improves sugars, crude fiber, some types of vitamins and minerals, but low level of starch and loss of total dry matter has been required to help betterment of some health conditions. At same time, by removing of wheat from a person's diet has also to help other [8].

Utilization of grain utilization increases betaglycan and more dissolvable fiber into a man's diet. The grain also contains dissolvable and insoluble fiber. Dissolvable fiber was strong in minimizing blood cholesterol and reduced the heart diseases. Dissolvable fiber was also disposition in maintenance of sugar and lessening the diabetes. Insoluble fiber also helps to keep the body safe and sound. Insoluble fiber may help in reduction of particular malignancies like, colon tumor. Presence of gluten in grains of wheat and rye helps to minimize the celiac sickness. Celiac disease is capable with osteoporosis and bone setback. The grains of wheat and rye also help to reduce the gastrointestinal symptoms inside fourteen days [9].

The grains are also rich in many vitamins and micronutrients. The grain contains many vitamins and minerals like; niacin, vitamin- $6, \mathrm{~B}_{3}$, thiamine, selenium, squeeze, magnesium, zinc, phosphorus and copper. These minerals are the growth regulators enhance growth of human being and fulfills their deficiency in human body [10].

The growth of a body mainly depends upon the proper diets which are supplemented with many vitamins and minerals. Now a days the efforts have been made to reduce the starch contents and minimize the health hazardous effects of some plant enzymes associated with barley [11].

\section{Health Benefits}

Pearled can easily find in uttermost super markets. There were uttermost communally uses for pearled, from serving like rice to soups and stews. They were also used communally for animal feed, to sustained malt (an important ingredient in beer production), for seed and for human food applications. Malting is the process of germinating the seeds followed by drying. Malt can be used in production of beer, whiskey, vinegar. Malting grains sustained enzymes required to change grain's starch into sugars. It was also estimated that about two-thirds of crop has been used for pasturage, one-third for malting and about $2 \%$ for food directly.

Not only the grains were utilized house but it was estimated that about an amount of $\$ 155$ million is utilized on grain and its processed items, e.g. $\$ 44$ million for malt and malt removes and \$269 million or more is utilized during 1991 to 2000.In a rough estimate about 51 percent of the Barley grain is used in US for the human consumption. Forty-four percent was utilized for malt creation, 3 percent as seed and 2 percent for nourishment supplements. The grain was additionally utilized for stretching of starch, for nourishment or for synthetic industry. The grain has flexible Barley grain for completing meat dairy cattle in United States and was utilized as a part of food amazingly in geographic districts where maize can't be planted [12].

The barley plant at vegetative (green stage) is used as feed to domesticated animals. Dry stalks and leaves are also utilized for animal feed in combination of seed cake. Straw was utilized as low calorie sustenance and bedding for animals. The grain can be encouraged to hamburger steers, dairy steers, sheep, swine, and poultry. There are certain problems in the malting process which should be sustained properly if in any case they are not checked properly it will results in loss of malt quality and it was suggested that malt quality is the main factor which encourages the market acceptability of the product [13].

The grain has utilized as a part of refreshments and is a key fixing in brew and whisky generation. Two-push grain was generally utilized as a part of German and English lagers. Six-push grain was customarily utilized as a part of US lagers yet the two assortments were in like manner utilization now. Nonalcoholic beverages for example its grain water and broiled Barley grain tea have been made by bubbling grain in water [14].

In Italy the grain has utilized as espresso substitute caffèdorzo (espresso of grain). The drink got from ground grain and it was set up as a coffee (it can be readied utilizing percolators, channel machines or cafeterias). It broadly utilized amid the time frame and World War-II as Italy was influenced by ban and attempted to import espresso. It was additionally a less expensive choice for poor families frequently developed and simmered at home in the period. Later it was advanced and sold as an espresso substitute for kids. These days it has encountered a recovery and it may be viewed as a few Italians' most loved other option to espresso when for wellbeing reasons caffeine drinks are not prescribed [15].

\section{MATERIAL AND METHODS Experimental Material and Layout}

In this experiment Pakistani variety of Haider 93 was used for developing the lemon (RTD). The Variety Haider-93 was obtained from the Ayub Agriculture Research Institute (AARI) Faisalabad. Then the seeds were sprouted in wet cloth and sprouted barley was dried in the oven at $100^{\circ} \mathrm{C}$. After drying the sprouted seeds were ground with the help of grinder to 
obtain the uniform and fine powder. The powder was utilized in the manufacture of Lemon RTD.

The Sprouted powder was combined with fresh powder of barley to enhance the nutritional value. Physical (pH, Acidity, brix, Sensory Attributes, Color, Flavor, Taste) analysis of prepared Lemon RTD storage life up to 90 days. The general composition is given for the utilization of $100 \mathrm{~g}$ in the Table- 1 .

The treatment plain is presented in Table-2. The overall change in the sprouted powder varied in the all trials but other parameter as acidity were same used for the product development.

Table-1: Composition of $100 \mathrm{~g}$

\begin{tabular}{|c|l|c|}
\hline Sr. No & Components & Qty per $\mathbf{1 0 0 g}$ \\
\hline 1 & Moisture & 12.1 \\
\hline 2 & Protein & 11.1 \\
\hline 3 & Lipids & 2.1 \\
\hline 4 & Carbohydrates & 62.7 \\
\hline 5 & Fiber & 9.7 \\
\hline 6 & Mineral & 2.3 \\
\hline
\end{tabular}

(Belitz et al., 2009 [16])

Table-2: Treatment Plan

\begin{tabular}{|r|r|r|}
\hline Treatments & Barley Powder in grams & Sprouted Barley powder in grams \\
\hline T1 & 25 & 0 \\
\hline T2 & 24 & 1 \\
\hline T3 & 23 & 2 \\
\hline T4 & 22 & 3 \\
\hline T5 & 21 & 4 \\
\hline
\end{tabular}

\section{Sensory evaluation of Lemon RTD}

The Lemon RTD was evaluated for various sensory quality attributes like color, flavor, taste, and over all acceptability followed by seven semi trained the method outlined by Amerine et al., [17] with a 9 point hedonic scale.

\section{Shelf Life}

The shelf life of the product was evaluated after 30 days interval and overall shelf life were determined up to 90 days. The RTD was analyzed at 0,30, 60 and 90 days and quality check pH, acidity and over all acceptances were analyzed.

\section{Moisture Determination Principle}

The moisture of the sample was lost by volatilization caused by heat. The amount of material left after the removal of the moisture was the dry matter.

The fresh weight of the sample was weighed on electrical balance then it was oven dried at $100^{\circ} \mathrm{C}$ for 4 hours. Then the dried weight was measured. The moisture contents were computed from following formula.

$$
\text { Moisture }=\frac{\text { Fresh weight }- \text { Dry weight }}{\text { Fresh weight }} \times 100
$$

\section{Ash Determination}

For the determination of ash the sample of measured quantity was ignited at $\mathrm{t} 600^{\circ} \mathrm{C}$ to burn off all organic material the inorganic material which does not volatilized at that temperature has called ash. Then the remaining ash was weighed on electrical balance. The Ash \% was determined by following formula;

$$
\text { Ash } \%=\frac{\text { Weight of sample before buringi-Weightof sample after burning }}{\text { Weight of sample before burning }} \times 100
$$

\section{Protein Contents}

The Kjeldhal's method was used to determine the crude protein in barley sprouted powder and analyzed with the given method for crude protein. This method is given in the AACC [18]. In this method the samples were collected and put in the digestion tube. The concentrated sulphuric acid was used which $98 \%$ pure it was $20 \mathrm{ml}$ for digestion. As a catalyst the digestion tablet was used. It acted as a catalyst for the mixing of the material. This process was continued for more than 4 to 5 hours. This was continued until the transparent material was appeared. After that stop the digestion. Dilute the material in the $250 \mathrm{ml}$ flask. For the sake of release of ammonia gas the $40 \% \mathrm{NaOH}$ solution was added $70 \mathrm{ml}$ in that flask to neutralize that volume of the sample which was digested in the pure
HCL. The neutralization will be done in the Kjeldhal's Apparatus. The ammonia activist was stuck in $4 \%$ boric acid solution containing indicators (methyl red). The titration against Sulphuric acid was done to collect the amount of ammonia until the purple color was obtained. The blank solution without sample and the sample containing reading was compared to each other and the result was obtained.

$$
\mathbf{N}(\%)=\frac{0.0014 \times \text { Vol. of } 0.1 \mathrm{~N} \mathrm{H}_{2} \mathrm{SO}_{4} \times 250 \mathrm{~mL}}{\text { Vol. of Diluted Sample } \times \text { Wt. of Original Sample }}
$$

Protein (\%) was then calculated by multiplying N (\%) with factor 6.25.

Crude Protein $(\%)=$ Nitrogen $(\%) \times 6.25$ 


\section{Physical Analysis}

\section{Determination of $\mathrm{TSS} / \mathrm{Brix}^{\circ}$}

The effect of storage on TSS was directly observed by using manually operated refractometer according to Method No. 931-12 of AOAC [19].

\section{Determination of $\mathbf{p H}$}

For the determination of $\mathrm{pH}$ a juice sample of $50-70 \mathrm{ml}$ is taken in a beaker and $\mathrm{pH}$ was recorded with the help of $\mathrm{pH}$ Meter (Model pH 211, HANNA Instruments, Romania) according to Method No. 94527 of AOAC [19].

\section{Determination of Acidity of Lemon RTD Principle}

A weighed volume of a sample was titrated against standard soluble base arrangement within the sight of phenolphthalein as inward pointer to light pink shading and titrate able corrosiveness was communicated expectedly in $\mathrm{g}$ corrosive per $100 \mathrm{~g}$ or $100 \mathrm{~mL}$. Factor for computation of causticity was done against the premise of centralization of dominating corrosive in that item.

\section{Potentiometric Method}

The purpose of lacked of bias i.e. the end purpose of titration may likewise be resolved utilizing a pH meter. The extracted strategy utilized will rely upon the maker guide lines. However the accompanying will give a general guide.

\section{Calculation}

Acidity $\%=$ volume of titrate $\times$ normality of titrate $\times$ equivalent of acid Sample volume

The Sample Preparation Method for the Analysis of Phenolic Compounds Barley sprouted powder Drying of barley sprouted powder:

Take the barley sprouted powder and dry it at room temperature under shade

\section{Extraction:}

1. Then took $10 \mathrm{~g}$ of barley sprouted powder and dip in $100 \mathrm{ml}$ methanol for about 10 days (plant will dissolve in the chemical)

2. When barley sprouted powder became dissolved filter it to get the filtrate.
3. Then dried it to remove the solvent in vacuum drying oven.

4. When about $2-3 \mathrm{~g}$ plant extracted was remained then took it for further analysis.

Yield $\%=\frac{3 \mathrm{~g} \text { of plant extract }}{10 \mathrm{~g} \text { ofpowder plant material }} \times 100$

\section{Sample preparation for HPLC analysis}

1. Take $50 \mathrm{mg}$ of barley sprouted powder extract and add $16 \mathrm{ml}$ of $\mathrm{DDH}_{2} \mathrm{O}$ and $24 \mathrm{ml}$ methanol

2. Shakes for $5 \mathrm{~min}$. then add $10 \mathrm{ml}$ of 6 molar $\mathrm{HCl}$

3. Kept for $2 \mathrm{hrs}$. in oven at $90^{\circ} \mathrm{C}$

4. Filter through micro filters of 0.2 OR 0.4 microns.

5. Sample it to analyze through HPLC

\section{STATISTICAL ANALYSIS}

The collected data was subjected to analysis of variance following the method as by Steel et al., [20]. The treatments means were compared by LSD analysis.

\section{RESULTS AND DISCUSSION Sensory Evaluation Color}

In the sensory evaluation of the product the color played an important role. Color of the products has reflected light. From white all color combinations has been made. The color of the product is most important for attracting the attention of the customer.

The analysis of variance of Lemon Barley RTD has given in Table- 3 . The results indicated that the analysis of variance for different treatments were significant $(\mathrm{p} \leq 0.014)$. While the days and interaction (treatments $\times$ days) were differed non-significantly $(\mathrm{p}>0.05)$. The average mean of the all treatments $\left(\mathrm{T}_{1}, \mathrm{~T}_{2}\right.$, $\mathrm{T}_{3}, \mathrm{~T}_{4}, \mathrm{~T}_{5}$ ) for color were $7.4,7.73,7.55,7.70$ and 6.65 respectively and at storage $(0,30,60,90$ days $)$ as presented in Table-4. The maximum mean value for color is recorded from treatment 4 (7.70) while minimum mean value for color is recorded from treatment $5(6.65)$. So by this we concluded that the color of the product was same but in the last trial color also decreases little bit as the control at every interval 0-90 days.

Table-3: Analysis of variance for color of Lemon Barley RTD

\begin{tabular}{|l|l|l|l|l|l|}
\hline SOV & DF & SS & MS & F value & P value \\
\hline Treatment & 4 & 31.220 & 7.80500 & $18.81^{* *}$ & 0.0000 \\
\hline Days & 3 & 0.375 & 0.12500 & $0.30_{\mathrm{NS}}$ & 0.8245 \\
\hline Treatment*Days & 12 & 3.900 & 0.32500 & $0.78_{\mathrm{NS}}$ & 0.6674 \\
\hline Error & 180 & 74.700 & 0.41500 & & \\
\hline Total & 199 & 110.195 & & & \\
\hline \multicolumn{6}{c|}{ Significant $(\mathrm{p} \leq 0.014)$} \\
$* *$ & Highly significant $(\mathrm{p} \leq 0.05)$ \\
NS = Non-significant $(\mathrm{p}>0.05)$
\end{tabular}


Table-4: Mean comparison for Color of Lemon RTD

\begin{tabular}{|r|r|r|r|r|r|}
\hline \multirow{2}{*}{ Treatment } & \multicolumn{3}{|c|}{ Mays } & \multirow{2}{*}{ Mean } \\
\cline { 2 - 5 } & $\mathbf{1}$ & $\mathbf{3 0}$ & $\mathbf{6 0}$ & $\mathbf{9 0}$ & \\
\hline $\mathbf{T}_{\mathbf{1}}$ & $7.50 \mathrm{ABC}$ & $7.2000 \mathrm{CD}$ & $7.5000 \mathrm{ABC}$ & $7.4000 \mathrm{BC}$ & $7.40 \mathrm{~B}$ \\
\hline $\mathbf{T}_{\mathbf{2}}$ & $8.0000 \mathrm{~A}$ & $7.5000 \mathrm{ABC}$ & $7.8000 \mathrm{AB}$ & $7.6000 \mathrm{ABC}$ & $7.73 \mathrm{~A}$ \\
\hline $\mathbf{T}_{\mathbf{3}}$ & $7.5000 \mathrm{ABC}$ & $7.6000 \mathrm{ABC}$ & $7.7000 \mathrm{ABC}$ & $7.5000 \mathrm{ABC}$ & $7.55 \mathrm{AB}$ \\
\hline $\mathbf{T}_{\mathbf{4}}$ & $7.5000 \mathrm{AB}$ & $7.8000 \mathrm{AB}$ & $7.4000 \mathrm{BC}$ & $7.8000 \mathrm{AB}$ & $7.70 \mathrm{~A}$ \\
\hline $\mathbf{T}_{\mathbf{5}}$ & $6.7000 \mathrm{DE}$ & $6.8000 \mathrm{DE}$ & $6.5000 \mathrm{E}$ & $6.6000 \mathrm{E}$ & $6.65 \mathrm{C}$ \\
\hline Mean & $7.4800 \mathrm{~A}$ & $7.3800 \mathrm{~A}$ & $7.3800 \mathrm{~A}$ & $7.3800 \mathrm{~A}$ & \\
\hline
\end{tabular}

\section{Means showing different letters differed significantly $(\mathbf{p} \leq \mathbf{0 . 0 5})$}

( $\mathrm{T}_{1} /$ Control-100\% powder; $\mathrm{T}_{2-1}$ Gram sprouted powder and 24 gram powder; $\mathrm{T}_{3-2}$ Gram sprouted powder and 23 gram powder; $\mathrm{T}_{4-3}$ Gram sprouted powder and 25 gram powder; $\mathrm{T}_{5-}{ }_{4} \mathrm{Gram}$ sprouted powder and 25 gram powder

\section{Flavor}

In the sensory evaluation of the product the Flavored played an important role. As the final demand of the product from the customer is mainly depends on the flavor and taste. If the flavor is according to the liking of the customer then the product will be highly demanded in the market of the flavor is not satisfactory then the.

The analysis of variance of Lemon Barley RTD has given in Table-5. It was evident from the analysis of variance that all the treatments were differed highly significantly $(\mathrm{p} \leq 0.014)$ for taste of Lemon Barley RTC, while the days and interaction (treatments $x$ days) were differed non-significantly $(p>0.05)$. The mean comparison (Table-6) showed that all the treatments $\left(\mathrm{T}_{1}, \mathrm{~T}_{2}, \mathrm{~T}_{3}, \mathrm{~T}_{4}, \mathrm{~T}_{5}\right)$ attained the value of $7.325,7.550,7.475,7.500$ and 5.525 respectively for flavor. The maximum mean value for flavor (7.55) was observed from $\mathrm{T}_{5}$ and minimum mean value for flavor was recorded from $T_{1}$ (7.32). In case of storage $(0,30$, 60,90 days) the mean value for flavor ranged from 6.85 to 7.22.So it was concluded that the flavor of the product was same but in the last trial flavor also changes little bit as the control at every interval 0-90 days. At 0,30,60,90 days there was not so much difference in treatment \# $1,2,3$ and 4 while in the treatment number 5 significant differences from other in flavored.

Table-5: Analysis of variance for Flavor of Lemon RTD

\begin{tabular}{|l|l|l|l|l|l|}
\hline SOV & DF & SS & MS & F value & P value \\
\hline Treatment & 4 & 121.250 & 30.3125 & $66.46^{* *}$ & 0.0000 \\
\hline Days & 3 & 3.495 & 1.1650 & $2.55^{\text {NS }}$ & 0.0569 \\
\hline Treatment*Days & 12 & 3.030 & 0.2525 & $0.55^{\text {NS }}$ & 0.8766 \\
\hline Error & 180 & 82.100 & 0.4561 & & \\
\hline Total & 199 & 209.875 & & & \\
\hline \multicolumn{6}{c|}{$*$ Significant $(\mathrm{p} \leq 0.014)$} \\
$* *$ & Highly significant $(\mathrm{p} \leq 0.05)$ \\
NS $=$ Non-significant $(\mathrm{p}>0.05)$
\end{tabular}

Table-6: Mean comparison for Flavor of Lemon RTD

\begin{tabular}{|c|c|c|c|c|c|}
\hline \multirow[t]{2}{*}{ Treatment } & \multicolumn{4}{|l|}{ Days } & \multirow[t]{2}{*}{ Mean } \\
\hline & 1 & 30 & 60 & 90 & \\
\hline$T_{1}$ & $7.2000 \mathrm{AB}$ & $7.5000 \mathrm{AB}$ & $7.3000 \mathrm{AB}$ & $7.3000 \mathrm{AB}$ & $7.3250 \mathrm{~A}$ \\
\hline $\mathbf{T}_{2}$ & $7.5000 \mathrm{AB}$ & $7.5000 \mathrm{AB}$ & $7.5000 \mathrm{AB}$ & $7.7000 \mathrm{~A}$ & $7.5500 \mathrm{~A}$ \\
\hline $\mathbf{T}_{3}$ & $7.2000 \mathrm{AB}$ & $7.6000 \mathrm{AB}$ & $7.4000 \mathrm{AB}$ & $7.7000 \mathrm{~A}$ & $7.4750 \mathrm{~A}$ \\
\hline $\mathbf{T}_{4}$ & $7.1000 \mathrm{~B}$ & $7.6000 \mathrm{AB}$ & $7.7000 \mathrm{~A}$ & $7.6000 \mathrm{AB}$ & $7.5000 \mathrm{~A}$ \\
\hline $\mathbf{T}_{5}$ & $5.3000 \mathrm{C}$ & $5.3000 \mathrm{C}$ & $5.7000 \mathrm{C}$ & $5.8000 \mathrm{C}$ & $5.5250 \mathrm{~B}$ \\
\hline Mean & $6.8600 \mathrm{~B}$ & $7.1000 \mathrm{AB}$ & $7.1200 \mathrm{AB}$ & $7.2200 \mathrm{~A}$ & \\
\hline
\end{tabular}

Means showing different letters differed significantly $(\mathrm{p} \leq 0.05)$

*( $\mathrm{T}_{1} /$ Control-100\% powder; $\mathrm{T}_{2-1}$ Gram sprouted powder and 24 gram powder; $\mathrm{T}_{3-2}$ Gram sprouted powder and 23 gram powder; $\mathrm{T}_{4-3}$ Gram sprouted powder and 25 gram powder; $\mathrm{T}_{5-}{ }_{4} \mathrm{Gram}$ sprouted powder and 25 gram powder).
Taste

In the sensory evaluation of the taste of the product is most important quality attribute. As the product has a pleasant taste and according to demand of customer it is widely accepted by the customers. If the taste is not satisfactory then the product has no market value. 
The analysis of variance of Lemon Barley RTD is presented in Table-7. The analysis of variance revealed that treatments and storage (days) were highly significantly differed $(\mathrm{p} \leq 0.014)$ with each other in case of taste of Lemon Barley RTD, while the interaction (treatments $\times$ days) were differed nonsignificantly $(\mathrm{p}>0.05)$ for taste of Lemon Barley RTD. The mean comparison (Table-8) of all the treatments $\left(\mathrm{T}_{1}, \mathrm{~T}_{2}, \mathrm{~T}_{3}, \mathrm{~T}_{4}\right.$, and $\left.\mathrm{T} 5\right)$ were $7.875,7.825,6.750,5.875$ and 4.900 respectively. The maximum mean value for taste (7.87) was recorded from treatment 1 while minimum (5.87) were observed from treatment 4 . In case of storage $(0,30,60,90$ days $)$ the mean value for taste ranged from 6.48 to 6.80 . So by this we concluded that the taste of the product was same but in the last treatment flavor also changes little bit as the control at every interval 0-90 days. At 0,30, 60 and 90 days storage there was not so much difference in treatment $\mathrm{T}_{1}, \mathrm{~T}_{2}$ and $\mathrm{T}_{3}$. In case of treatments the treatment $\mathrm{T}_{4}$ and $\mathrm{T}_{5}$ is much more different from other treatments like $\mathrm{T}_{1}$, $\mathrm{T}_{2}$ and $\mathrm{T}_{3}$.

Table-7: Analysis of variance for Taste of Lemon RTD

\begin{tabular}{|l|l|l|l|l|l|}
\hline SOV & DF & SS & MS & F value & P value \\
\hline Treatment & 4 & 262.170 & 65.5425 & $186.38^{* *}$ & 0.0000 \\
\hline Days & 3 & 3.775 & 1.2583 & $3.58^{*}$ & 0.0151 \\
\hline Treatment*Days & 12 & 4.550 & 0.3792 & $1.08^{\text {NS }}$ & 0.3810 \\
\hline Error & 180 & 63.300 & 0.3517 & & \\
\hline Total & 199 & 333.795 & & & \\
\hline \multicolumn{6}{c}{$*$ Significant $(\mathrm{p} \leq 0.014)$} \\
** = Highly significant $(\mathrm{p} \leq 0.05)$ \\
NS = Non-significant $(\mathrm{p}>0.05)$
\end{tabular}

Table-8: Mean comparison for taste of Lemon RTD

\begin{tabular}{|l|l|l|l|l|l|}
\hline \multirow{2}{*}{ Treatment } & \multicolumn{4}{|c|}{ Days } & \multirow{2}{*}{ Mean } \\
\cline { 2 - 5 } & $\mathbf{1}$ & $\mathbf{3 0}$ & $\mathbf{6 0}$ & $\mathbf{9 0}$ & \\
\hline $\mathbf{T}_{\mathbf{1}}$ & $8.0000 \mathrm{~A}$ & $7.7000 \mathrm{~A}$ & $8.0000 \mathrm{~A}$ & $7.8000 \mathrm{~A}$ & $7.8750 \mathrm{~A}$ \\
\hline $\mathbf{T}_{\mathbf{2}}$ & $7.8000 \mathrm{~A}$ & $7.7000 \mathrm{~A}$ & $8.0000 \mathrm{~A}$ & $7.8000 \mathrm{~A}$ & $7.8250 \mathrm{~A}$ \\
\hline $\mathbf{T}_{\mathbf{3}}$ & $6.6000 \mathrm{BC}$ & $6.6000 \mathrm{BC}$ & $6.7000 \mathrm{~B}$ & $7.1000 \mathrm{~B}$ & $6.7500 \mathrm{~B}$ \\
\hline $\mathbf{T}_{\mathbf{4}}$ & $5.5000 \mathrm{EF}$ & $5.9000 \mathrm{DE}$ & $6.0000 \mathrm{DE}$ & $6.1000 \mathrm{CD}$ & $5.8750 \mathrm{C}$ \\
\hline $\mathbf{T}_{\mathbf{5}}$ & $4.5000 \mathrm{H}$ & $4.8000 \mathrm{GH}$ & $5.3000 \mathrm{FG}$ & $5.0000 \mathrm{FGH}$ & $4.9000 \mathrm{D}$ \\
\hline Mean & $6.4800 \mathrm{C}$ & $6.5400 \mathrm{BC}$ & $6.7600 \mathrm{AB}$ & $6.8000 \mathrm{~A}$ & \\
\hline
\end{tabular}

\section{Means showing different letters differed significantly $(p \leq \mathbf{0 . 0 5})$}

( $\mathrm{T}_{1} /$ Control-100\% powder; $\mathrm{T}_{2-1}$ Gram sprouted powder and 24 gram powder; $\mathrm{T}_{3-2}$ Gram sprouted powder and 23 gram powder; $\mathrm{T}_{4-3}$ Gram sprouted powder and 25 gram powder; $\mathrm{T}_{5-}{ }_{4} \mathrm{Gram}$ sprouted powder and 25 gram powder).

\section{Overall Acceptability}

The quality of a Lemon Barley RTD is determined by its overall acceptability the product is made in such a sense that it is widely acceptable among the consumer market.

The analysis of variance of Lemon Barley RTD has given in Table-9. The results indicated that the analysis of variance for different treatments and days (storage) were highly significant $(\mathrm{p} \leq 0.014)$. However in case of interaction (treatments $\times$ storage) on Lemon Barley RTD were non-significant $(\mathrm{p}>0.05)$ results were achieved.

The mean comparison for the all treatments $\left(\mathrm{T}_{1}, \mathrm{~T}_{2}, \mathrm{~T}_{3}, \mathrm{~T}_{4}, \mathrm{~T}_{5}\right)$ were $7.45,7.60,7.30,6.85$ and 5.60 respectively (Table-10). The maximum mean value for overall acceptability (7.60) was recorded from treatment 2 and minimum (5.60) is recorded from treatment 5 . In case of storage $(0,30,60,90$ days)the mean value for overall acceptability ranged from 6.60 to 7.20.The mean comparison showed significant differences for $T_{4}$ and $T_{5}$,while $T_{1}, T_{2}$ and $T_{3}$ were differed non-significantly in case of Lemon Barley RD.

Table-9: Analysis of variance for Overall acceptability of Lemon RTD

\begin{tabular}{|l|l|l|l|l|l|}
\hline SOV & DF & SS & MS & F value & P value \\
\hline Treatment & 4 & 105.80 & 26.20 & $66.23^{* *}$ & 0.0000 \\
\hline Days & 3 & 9.760 & 3.25 & $8.20^{* *}$ & 0.0000 \\
\hline Treatment & 12 & 7.440 & 0.62 & $1.56^{\text {NS }}$ & 0.1060 \\
\hline Error & 180 & 71.400 & 0.39 & & \\
\hline Total & 199 & 193.680 & & & \\
\hline \multicolumn{7}{c|}{$*=$ Significant $(\mathrm{p} \leq 0.014)$} \\
& $* *=$ Highly significant $(\mathrm{p} \leq 0.05)$ \\
NS $=$ Non-significant $(\mathrm{p}>0.05)$
\end{tabular}


Table-10: Mean comparison for overall acceptability of Lemon RTD

\begin{tabular}{|r|r|r|r|r|r|}
\hline \multirow{2}{*}{ Treatment } & \multicolumn{3}{|c|}{ Days } & \multirow{2}{*}{ Mean } \\
\cline { 2 - 5 } & $\mathbf{1}$ & $\mathbf{3 0}$ & $\mathbf{6 0}$ & $\mathbf{9 0}$ & \\
\hline $\mathbf{T}_{\mathbf{1}}$ & $7.6000 \mathrm{AB}$ & $7.3000 \mathrm{ABCD}$ & $7.5000 \mathrm{ABC}$ & $7.4000 \mathrm{ABC}$ & $7.4500 \mathrm{AB}$ \\
\hline $\mathbf{T}_{\mathbf{2}}$ & $7.2000 \mathrm{BCDE}$ & $7.6000 \mathrm{AB}$ & $7.8000 \mathrm{~A}$ & $7.8000 \mathrm{~A}$ & $7.6000 \mathrm{~A}$ \\
\hline $\mathbf{T}_{\mathbf{3}}$ & $6.7000 \mathrm{EF}$ & $7.5000 \mathrm{ABC}$ & $7.4000 \mathrm{ABC}$ & $7.6000 \mathrm{AB}$ & $7.3000 \mathrm{~B}$ \\
\hline $\mathbf{T}_{\mathbf{4}}$ & $6.2000 \mathrm{FG}$ & $7.0000 \mathrm{CDE}$ & $7.4000 \mathrm{ABC}$ & $6.8000 \mathrm{DE}$ & $6.8500 \mathrm{C}$ \\
\hline $\mathbf{T}_{\mathbf{5}}$ & $5.3000 \mathrm{I}$ & $5.6000 \mathrm{HI}$ & $5.9000 \mathrm{GH}$ & $5.6000 \mathrm{HI}$ & $5.6000 \mathrm{D}$ \\
\hline Mean & $6.6000 \mathrm{~B}$ & $7.0000 \mathrm{~A}$ & $7.0400 \mathrm{~A}$ & $7.2000 \mathrm{~A}$ & \\
\hline
\end{tabular}

\section{Means showing different letters differed significantly $(p \leq 0.05)$}

$\left(\mathrm{T}_{1} /\right.$ Control-100\% powder; $\mathrm{T}_{2-1}$ Gram sprouted powder and 24 gram powder; $\mathrm{T}_{3-2}$ Gram sprouted powder and 23 gram powder; $\mathrm{T}_{4-3}$ Gram sprouted powder and 25 gram powder; $\mathrm{T}_{5-4}$ Gram sprouted powder and 25 gram powder).

\section{Chemical Analysis of Lemon Barley RTD}

\section{PH}

PH was important in Lemon Barley RTD as it helps to change the sugar into inverted sugars in order to prevent the crystallization of Lemon Barley RTD. If the $\mathrm{pH}$ was not adjusted then the Lemon Barley RTD has been deteriorated and has effect on the sensory attributes at different storage level. PH of the food has the inverse relationship with the hydrogen ions present in the food.

The analysis of variance of Lemon Barley RTD has given in Table-11. The results indicated that all the treatments, days (storage) and interaction (treatments $\times$ days) were differed significantly $(\mathrm{p} \leq 0.014)$. The mean comparison (Table-12) showed that among all the treatments $\left(\mathrm{T}_{1}, \mathrm{~T}_{2}, \mathrm{~T}_{3}, \mathrm{~T}_{4}, \mathrm{~T}_{5}\right)$ attained the mean value of 3.5342 , $3.4892,3.3850,3.3575$ and 3.3017, respectively. The maximum mean value for $\mathrm{pH}$ (3.57) was recorded from $\mathrm{T}_{4}$ and minimum mean value (3.30) was recorded from $\mathrm{T}_{5}$.In case of storage $(0,30,60,90$ days) the mean value ranged from 6.60-7.20.The mean values of $\mathrm{pH}$ decreased during the storage of 90 days from (Day 1 to Day 90). The decrease in $\mathrm{pH}$ value is directly associated to the increase in the acidity of samples. The decrease in $\mathrm{pH}$ value with the storage might be due the formation of acidic compounds from the microbes that increase the hydrogen ions.

Table-11: Analysis of variance for pH of Lemon RTD

\begin{tabular}{|l|l|l|l|l|l|}
\hline SOV & DF & SS & MS & F value & P value \\
\hline Treatment & 3 & 0.10590 & 0.03530 & $423.59^{* *}$ & 0.0000 \\
\hline Days & 4 & 0.44089 & 0.11022 & $1322.67 * *$ & 0.0000 \\
\hline Treatment*Days & 12 & 0.00204 & 0.00017 & $2.04 *$ & 0.0454 \\
\hline Error & 40 & 0.00333 & 0.00008 & & \\
\hline Total & 59 & 0.55217 & & & \\
\hline & $* *$ Significant $(\mathrm{p} \leq 0.014)$ \\
& NS Highly significant $(\mathrm{p} \leq 0.05)$ \\
& Non-significant $(\mathrm{p}>0.05)$
\end{tabular}

Table-12: Mean comparison for $\mathrm{pH}$ of Lemon RTD

\begin{tabular}{|c|c|c|c|c|c|}
\hline \multirow[t]{2}{*}{ Treatment } & \multicolumn{4}{|c|}{ Days } & \multirow[t]{2}{*}{ Mean } \\
\hline & 1 & 30 & 60 & 90 & \\
\hline $\mathrm{T}_{1}$ & $3.5467 \mathrm{~B}$ & $3.5000 \mathrm{D}$ & $3.4667 \mathrm{EF}$ & $3.4433 \mathrm{G}$ & $3.5342 \mathrm{~A}$ \\
\hline $\mathrm{T}_{2}$ & $3.5933 \mathrm{~A}$ & $3.5500 \mathrm{~B}$ & $3.5167 \mathrm{C}$ & $3.4767 \mathrm{E}$ & $3.4892 \mathrm{~B}$ \\
\hline $\mathrm{T}_{3}$ & $3.4533 \mathrm{FG}$ & $3.4000 \mathrm{H}$ & $3.3633 \mathrm{~J}$ & $3.3233 \mathrm{~L}$ & $3.3850 \mathrm{C}$ \\
\hline $\mathrm{T}_{4}$ & $3.4000 \mathrm{H}$ & $3.3800 \mathrm{I}$ & $3.3433 \mathrm{~K}$ & $3.3067 \mathrm{M}$ & $3.3575 \mathrm{D}$ \\
\hline $\mathrm{T}_{5}$ & $3.3667 \mathrm{IJ}$ & 3.3167 LM & $3.2800 \mathrm{~N}$ & $3.2433 \mathrm{O}$ & $3.3017 \mathrm{E}$ \\
\hline Mean & $3.4720 \mathrm{~A}$ & $3.4293 \mathrm{~B}$ & $3.3940 \mathrm{C}$ & $3.3587 \mathrm{D}$ & \\
\hline
\end{tabular}

\section{Means showing different letters differed} significantly $(\mathrm{p} \leq \mathbf{0 . 0 5})$

$\left(\mathrm{T}_{1} /\right.$ Control-100\% Barley powder; $\mathrm{T}_{2-1}$ Gram sprouted barley powder and 24 gram barley powder; $\mathrm{T}_{3-}$ ${ }_{2}$ Gram sprouted barley powder and 23 gram barley powder; $\mathrm{T}_{4-3}$ Gram sprouted barley powder and 25 gram barley powder; $\mathrm{T}_{5-4}$ Gram sprouted barley powder and 25 gram barley powder).
TSS

Total soluble solids represent the dissolved solids in the Lemon Barley RTD. Sugar was the most common soluble solid while Lemon Barley RTD was a mixture of different ingredients such as sugar, lemon juice, Barley powder and preservatives. All these ingredients contributed to the TSS of Lemon Barley RTD. 
The analysis of variance of Lemon Barley RTD has given in Table-13. Analysis of variance showed highly significant difference $(p \leq 0.014)$ for treatments, days (storage) and interaction (treatments and days).

The mean comparison showed that all the treatments $\left(\mathrm{T}_{1}, \mathrm{~T}_{2}, \mathrm{~T}_{3}, \mathrm{~T}_{4}, \mathrm{~T}_{5}\right)$ showed the mean value of $12.217, \quad 12.392, \quad 12.133, \quad 12.467$ and 12.575, respectively. In case of storage $(0,30,60,90$ days) the mean value ranged from 12.02-12.70.The maximum mean value was recorded for $T_{5}(12.575)$ while the $T_{3}$ showed minimum value for TSS (12.133). The increase in the TSS of Lemon Barley RTD was due to the fact the components of Lemon Barley RTD soluble during the storage. The increment in TSS of Lemon Barley RTD may be because the polysaccharides such as gums and pectin undergo acid hydrolysis [22].

Table-13: Analysis of variance for TSS of Lemon RTD

\begin{tabular}{|l|l|l|l|l|l|}
\hline SOV & DF & SS & MS & F value & P value \\
\hline Treatment & 3 & 0.10590 & 0.03530 & $423.59 * *$ & 0.0000 \\
\hline Days & 4 & 0.44089 & 0.11022 & $1322.67 * *$ & 0.0000 \\
\hline Treatment*Days & 12 & 0.00204 & 0.00017 & $2.04 *$ & 0.0454 \\
\hline Error & 40 & 0.00333 & 0.00008 & & \\
\hline Total & 59 & 0.55217 & & & \\
\hline \multicolumn{6}{|c|}{ Significant $(\mathrm{p} \leq 0.014)$} \\
$* *$ \\
NS Highly significant $(\mathrm{p} \leq 0.05)$ \\
Non-significant $(\mathrm{p}>0.05)$
\end{tabular}

Table-14: Mean comparison for TSS of Lemon RTD

\begin{tabular}{|l|l|l|l|l|l|}
\hline \multirow{2}{*}{ Treatment } & \multicolumn{4}{|l|}{ Days } & \multirow{2}{*}{ Mean } \\
\cline { 2 - 5 } & $\mathbf{1}$ & $\mathbf{3 0}$ & $\mathbf{6 0}$ & $\mathbf{9 0}$ & \\
\hline $\mathbf{T}_{\mathbf{1}}$ & $11.900 \mathrm{~K}$ & $12.100 \mathrm{I}$ & $12.333 \mathrm{G}$ & $12.533 \mathrm{E}$ & $12.217 \mathrm{D}$ \\
\hline $\mathbf{T}_{\mathbf{2}}$ & $12.000 \mathrm{~J}$ & $12.300 \mathrm{G}$ & $12.533 \mathrm{E}$ & $12.733 \mathrm{~B}$ & $12.392 \mathrm{C}$ \\
\hline $\mathbf{T}_{\mathbf{3}}$ & $11.800 \mathrm{~L}$ & $12.000 \mathrm{~J}$ & $12.233 \mathrm{H}$ & $12.500 \mathrm{E}$ & $12.133 \mathrm{E}$ \\
\hline $\mathbf{T}_{\mathbf{4}}$ & $12.100 \mathrm{I}$ & $12.300 \mathrm{G}$ & $12.600 \mathrm{D}$ & $12.867 \mathrm{~A}$ & $12.467 \mathrm{~B}$ \\
\hline $\mathbf{T}_{\mathbf{5}}$ & $12.300 \mathrm{G}$ & $12.433 \mathrm{~F}$ & $12.667 \mathrm{C}$ & $12.900 \mathrm{~A}$ & $12.575 \mathrm{~A}$ \\
\hline Mean & $12.020 \mathrm{D}$ & $12.227 \mathrm{C}$ & $12.473 \mathrm{~B}$ & $12.707 \mathrm{~A}$ & \\
\hline
\end{tabular}

\section{Means showing different letters differed significantly $(p \leq \mathbf{0 . 0 5})$}

( $\mathrm{T}_{1} /$ Control-100\% Barley powder; $\mathrm{T}_{2-1}$ Gram sprouted barley powder and 24 gram barley powder; $\mathrm{T}_{3-}$ ${ }_{2}$ Gram sprouted barley powder and 23 gram barley powder; $\mathrm{T}_{4-3}$ Gram sprouted barley powder and 25 gram barley powder; $\mathrm{T}_{5-}{ }_{4} \mathrm{Gram}$ sprouted barley powder and 25 gram barley powder).

\section{Acidity}

The percentage of acidity in the Lemon Barley RTD was important in order to have the appropriate taste and storage. For the stability and shelf life of Lemon Barley RTD acidity have a crucial role. The acidity of the Drink was combined measure of organic acids in the sugar and acids added during the preparation of Lemon Barley RTD. 


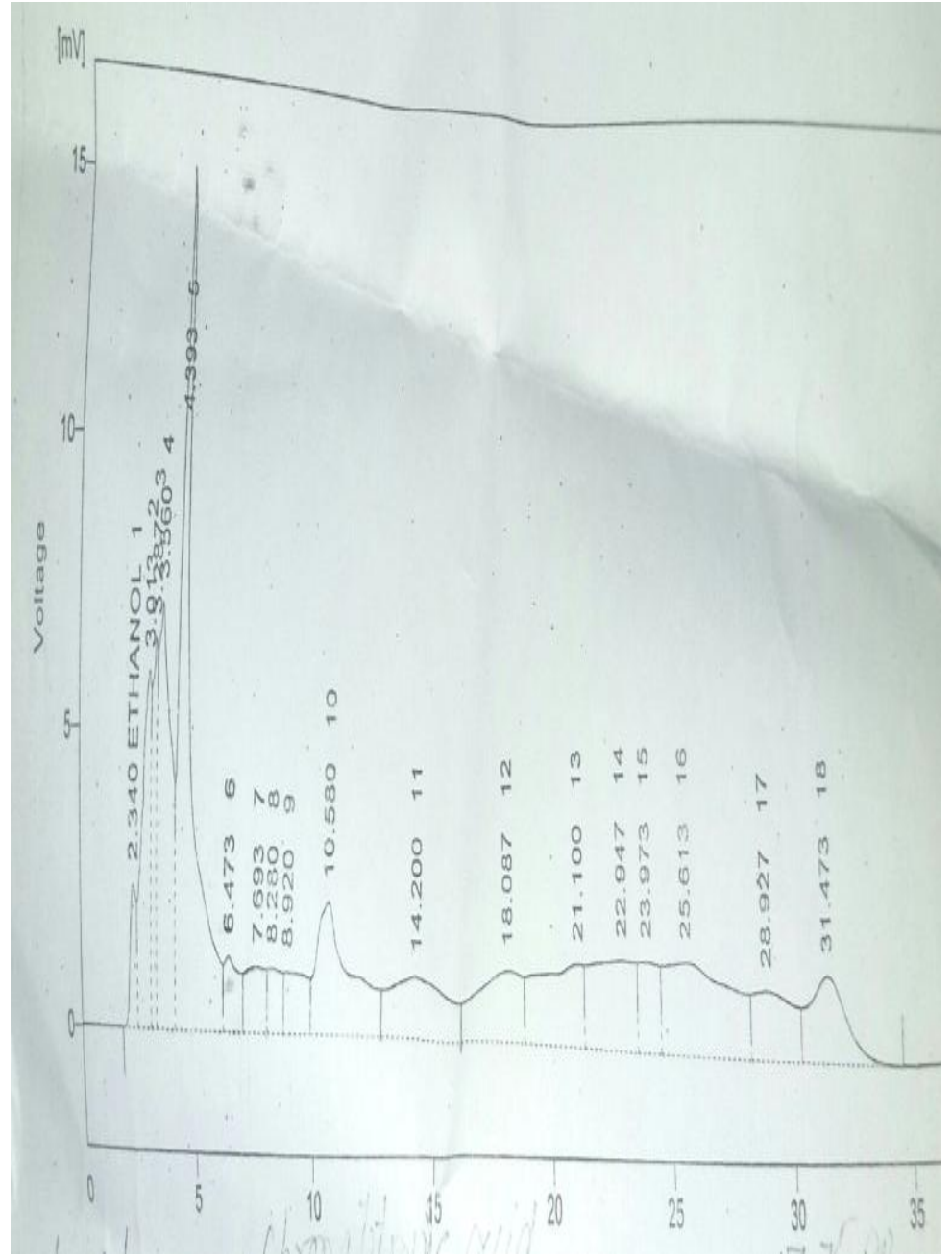

The analysis of variance of Lemon Barley RTD is presented in in Table-15. The analysis of variance suggested that all the treatments and days (storage) time were differed highly significantly $(\mathrm{p} \leq$ 0.014) for Lemon Barley RTD. While the interaction (treatments $\times$ storage) were differed non-significantly in case of acidity of Lemon Barley RTD. The mean value for all the treatments $\left(\mathrm{T}_{1}, \mathrm{~T}_{2}, \mathrm{~T}_{3}, \mathrm{~T}_{4}, \mathrm{~T}_{5}\right)$ were 0.2050 , $0.2242,0.2142,0.2250$ and 0.2425 , respectively (Table$16)$ and the mean vale for storage $(0,30,60,90$ days $)$ were ranged from 0.1860 to 0.2613 . The maximum mean value was recorded for $T_{5}(0.2425)$ while the $T_{3}$ has minimum value (0.2142) for acidity in Lemon Barley RTD. According to the mean values the acidity of Lemon Barley RTD increased during the storage of 90 days from (Day 1) to (Day 90). The increase in the acidity of Lemon Barley RTD might be due to the increase in the concentration of acids that are weakly ionized. The rise in acidity might be due to the breakdown of polysaccharides as well as reducing sugars are being oxidized in addition to the degradation of pectin into pectin acid and breakdown of ascorbic acid.

Table-15: Analysis of variance for acidity of Lemon Barley RTD

\begin{tabular}{|l|l|l|l|l|l|}
\hline SOV & DF & SS & MS & F value & P value \\
\hline Treatment & 3 & 0.04751 & 0.01584 & $263.95^{* *}$ & 0.0000 \\
\hline Days & 4 & 0.00941 & 0.00235 & $39.21^{* *}$ & 0.0000 \\
\hline Treatment*Days & 12 & 0.00050 & 0.00004 & $0.69^{\text {NS }}$ & 0.7511 \\
\hline Error & 40 & 0.00240 & 0.00006 & & \\
\hline Total & 59 & 0.05982 & & & \\
\hline \multicolumn{6}{c|}{ Significant $(\mathrm{p} \leq 0.014)$} \\
$* *$ & Highly significant $(\mathrm{p} \leq 0.05)$ \\
NS $=$ Non-significant $(\mathrm{p}>0.05)$
\end{tabular}


Table-16: Mean comparison for Acidity of Lemon Barley RTD

\begin{tabular}{|c|c|c|c|c|c|}
\hline \multirow[t]{2}{*}{ Treatment } & \multicolumn{4}{|c|}{ Days } & \multirow[t]{2}{*}{ Mean } \\
\hline & 1 & 30 & 60 & 90 & \\
\hline $\mathbf{T}_{1}$ & $0.1733 \mathrm{~K}$ & $0.1900 \mathrm{IJ}$ & $0.2133 \mathrm{FG}$ & $0.2433 \mathrm{CD}$ & $0.2050 \mathrm{D}$ \\
\hline $\mathbf{T}_{2}$ & $0.1900 \mathrm{IJ}$ & $0.2100 \mathrm{GH}$ & $0.2333 \mathrm{DE}$ & $0.2633 \mathrm{~B}$ & $0.2242 \mathrm{~B}$ \\
\hline $\mathbf{T}_{3}$ & $0.1800 \mathrm{JK}$ & $0.2000 \mathrm{HI}$ & $0.2233 \mathrm{EF}$ & $0.2533 \mathrm{BC}$ & $0.2142 \mathrm{C}$ \\
\hline $\mathbf{T}_{4}$ & $0.1867 \mathrm{~J}$ & $0.2133 \mathrm{FG}$ & $0.2400 \mathrm{D}$ & $0.2600 \mathrm{~B}$ & $0.2250 \mathrm{~B}$ \\
\hline $\mathbf{T}_{5}$ & $0.2000 \mathrm{HI}$ & $0.2267 \mathrm{E}$ & $0.2567 \mathrm{~B}$ & $0.2867 \mathrm{~A}$ & $0.2425 \mathrm{~A}$ \\
\hline Mean & $0.1860 \mathrm{D}$ & $0.2080 \mathrm{C}$ & $0.2333 \mathrm{~B}$ & $0.2613 \mathrm{~A}$ & \\
\hline
\end{tabular}

\section{Means showing different letters differed significantly $(\mathbf{p} \leq \mathbf{0 . 0 5})$}

* $\left(\mathrm{T}_{1} /\right.$ Control-100\% Barley powder; $\mathrm{T}_{2-1}$ Gram sprouted barley powder and 24 gram barley powder; $\mathrm{T}_{3}$ -
${ }_{2}$ Gram sprouted barley powder and 23 gram barley powder; $\mathrm{T}_{4-3}$ Gram sprouted barley powder and 25 gram barley powder; $\mathrm{T}_{5-}{ }_{4} \mathrm{Gram}$ sprouted barley powder and 25 gram barley powder).

\section{HPLC analysis of sprouted powder}

Table-17: Result table- calculation method ISTD2

\begin{tabular}{|l|l|l|l|l|}
\hline Return time & $\begin{array}{l}\text { Area } \\
{[\mathbf{m V . s}]}\end{array}$ & $\begin{array}{l}\text { Area } \\
\mathbf{\%}\end{array}$ & $\begin{array}{l}\text { Amount } \\
{[\mathbf{g} / \mathbf{k g}]}\end{array}$ & $\begin{array}{l}\text { Amount } \\
\mathbf{\%}\end{array}$ \\
\hline 2.340 & 43.921 & 1.5 & 0.835 & 100.0 \\
\hline 3.013 & 152.543 & 5.3 & 0.000 & 0.0 \\
\hline 3.287 & 86.893 & 3.0 & 0.000 & 0.0 \\
\hline 3.560 & 274.413 & 9.6 & 0.000 & 0.0 \\
\hline 4.393 & 513.260 & 17.9 & 0.000 & 0.0 \\
\hline 6.473 & 54.036 & 1.9 & 0.000 & 0.0 \\
\hline 7.963 & 61.997 & 2.2 & 0.000 & 0.0 \\
\hline 8.280 & 41.874 & 1.5 & 0.000 & 0.0 \\
\hline 8.920 & 63.334 & 2.2 & 0.000 & 0.0 \\
\hline 10.580 & 208.254 & 7.3 & 0.000 & 0.0 \\
\hline 14.200 & 169.212 & 5.9 & 0.000 & 0.0 \\
\hline 18.087 & 155.057 & 5.4 & 0.000 & 0.0 \\
\hline 21.100 & 185.549 & 6.5 & 0.000 & 0.0 \\
\hline 22.947 & 193.761 & 6.8 & 0.000 & 0.0 \\
\hline 23.973 & 86.579 & 3.0 & 0.000 & 0.0 \\
\hline 25.613 & 292.693 & 10.2 & 0.000 & 0.0 \\
\hline 28.927 & 130.452 & 4.5 & 0.000 & 0.0 \\
\hline 31.473 & 153.497 & 5.4 & 0.000 & 0.0 \\
\hline Total & $\mathbf{2 8 6 7 . 3 2 6}$ & $\mathbf{1 0 0 . 0}$ & $\mathbf{0 . 0 0 0}$ & $\mathbf{0 . 0}$ \\
\hline & & & &
\end{tabular}

\section{HPLC}

High-performance liquid chromatography (HPLC) has a form of liquid chromatography which was used to separate compounds which were dissolved at solution. HPLC instruments consisted of a reservoir of mobile phase, a pump, an injector, a separation column, and a detector.

Sprouted powder was analyzed on this equipment to check the flavonoids and phenolic compound of the sprouted powder. The column used for this purpose is Shim-pack CLC-ODS (C-18), $25 \mathrm{~cm} \times$ 4.6min, $5 \mu \mathrm{m}$.Mobile phase for this purpose is used Gradient: $\mathrm{A}(\mathrm{H} 2 \mathrm{O}: \mathrm{AA}:-94: 6, \quad \mathrm{pH}=2.27), \quad \mathrm{B}(\mathrm{CAN}$ $100 \%), 0-15 \mathrm{~min}=15 \% \mathrm{~B}, 15-30=45 \% \mathrm{~B}, 30-45=100 \% \mathrm{~B}$. Flow rate for this purpose was used in $1 \mathrm{ml} / \mathrm{min}$. Detection was done with UV-Visible detector.280nm and temperature is RT. Calibration file was used as ethanol. Colum length was $100 \mathrm{~nm}$. The sample was run for the $35 \mathrm{~min}$ and the results were obtained in the graph.

Chemotropic acid was obtained at retention time 2.340 and its value was $17.75 \mathrm{ppm}$. Quarzitic was obtained at 3.013 retention time and its value was $8.08 \mathrm{ppm}$.Quarzitic is the flavonoid compound. Gallic acid which was also a phenolic compound obtained at 4.393 retention time and its value was $18.46 \mathrm{ppm}$ at retention times 14.200 the benzoic acid was obtained which has value of $17.91 \mathrm{ppm}$. At 18.087 Retention times the P-cumeric Acid was obtained which has value of $2.01 \mathrm{ppm}$. At 25.613 retention time the Cinamic acid was produced and value was $10.24 \mathrm{ppm}$.

\section{Chemical Analysis \\ Moisture Content}

Analysis of variance and comparison of mean for moisture \% in barley sprouted powder are presented 
in Table-18. Respectively. It was evidence from the analysis of variance that treatments were highly significantly differed with each other in case of moisture \%.

The significant differences for moisture \% were also reported by Mahjoub et al., [21] by his thought we can get that by sprouting one can get 6 to 10 $\mathrm{kg}$ of yield by sprouting one kilogram of sprouted.

The moisture $\%$ ranged from 70 to $74 \%$. The maximum moisture \% $(74 \%)$ was recorded from $\mathrm{S}_{1}$. The minimum moisture $\% 70 \%$ was recorded from $\mathrm{S}_{3}$. So it was concluded that $\mathrm{S}_{3}$ is the best as it results in minimum moisture $\%$ and improved the nutritional quality of barley. The more moisture contents results in poor quality.

Table-18: Moisture content of Sprouted barley

\begin{tabular}{|l|l|l|l|l|}
\hline \multirow{2}{*}{ Moisture \% } & \multicolumn{2}{|l|}{ Samples } & Mean \\
\cline { 2 - 4 } & $\mathrm{S}_{1}$ & $\mathrm{~S}_{2}$ & $\mathrm{~S}_{3}$ & \multirow{2}{*}{72} \\
\cline { 2 - 4 } & $74 \%$ & $70 \%$ & $72 \%$ & \\
\hline
\end{tabular}

\section{Ash Content}

Analysis of variance and comparison of mean for ash \% in barley sprouted powder are presented in Table-19 respectively. It was evidence from the analysis of variance that treatments were highly significantly differed with each other in case of Ash \%.

The significant differences for Ash \% were also reported by Mahjoub et al., [21] by his thought we can get that by sprouting one can get 6 to $10 \mathrm{~kg}$ of yield by sprouting one kilogram of sprouted. The Ash \% ranged from 4.5 to $5 \%$. The maximum ash \% (74\%) was recorded from $S_{1}$ and $S_{3}$. The minimum ash \% 4.5 $\%$ was recorded from $S_{2}$. So it was concluded that $S_{1}$ and $S_{3}$ is the best as it results in maximum ash \% and improved the nutritional quality of barley. The less ash contents results in poor quality.

Table-19: Ash content of Sprouted barley

\begin{tabular}{|l|l|l|l|l|}
\hline \multirow{2}{*}{ Ash \% } & \multicolumn{3}{|l|}{ Samples } & Mean \\
\cline { 2 - 4 } & $\mathrm{S}_{1}$ & $\mathrm{~S}_{2}$ & $\mathrm{~S}_{3}$ & \\
\cline { 2 - 4 } & $5.0 \%$ & $4.5 \%$ & $5.0 \%$ & 4.75 \\
\hline
\end{tabular}

\section{Protein Content}

Analysis of variance and comparison of mean for protein $\%$ in barley sprouted powder are presented in Table-20 respectively. It was evidence from the analysis of variance that treatments were highly significantly differed with each other in case of protein $\%$.

The significant differences for Protein \% were also reported by Mahjoub et al., [21] by his thought we can get that by sprouting one can get 6 to $10 \mathrm{~kg}$ of yield by sprouting one kilogram of sprouted.
The protein $\%$ ranged from 14.3 to $16.3 \%$. The maximum protein $\%(16.3 \%)$ was recorded from $\mathrm{S}_{1}$ .The minimum protein $\% 14.3 \%$ was recorded from $\mathrm{S}_{2}$. So it was concluded that $S_{1}$ is the best as it results in maximum protein $\%$ and improved the nutritional quality of barley. The less protein contents results in poor quality.

Table-20 Protein content of Sprouted barley

\begin{tabular}{|c|l|l|l|l|}
\hline \multirow{2}{*}{ Ash \% } & \multicolumn{2}{|l|}{ Samples } & Mean \\
\cline { 2 - 4 } & $\mathrm{S}_{1}$ & $\mathrm{~S}_{2}$ & $\mathrm{~S}_{3}$ & 14.9 \\
\cline { 2 - 4 } & $15 \%$ & $14.8 \%$ & $15 \%$ & \\
\hline
\end{tabular}

\section{CONCLUSION}

So it was concluded that the treatment enhance the quality of Lemon Barley RTD. The all treatments were analyzed after 30 days interval and found that the $\mathrm{pH}$ is decreased with the passages of time while the Brix and acidity increased. The sensory attributes results change after every interval and found that in treatment 4 and 5 is less as compared to 1, 2 and 3 . So in treatment 4 and 5 effect of flavonoids feels in change in taste and flavor. In HPLC analysis found Chemotropic acid was obtained at retention time 2.340 and its value was $17.75 \mathrm{ppm}$. Quarzitic was obtained at 3.013 retention time and its value was $8.08 \mathrm{ppm}$.Quarzitic is the flavonoid compound. Gallic acid which was also a phenolic compound was obtained at 4.393 retention time and its value was 18.46 ppm.at retention times 14.200 the benzoic acid was obtained which has value of $17.91 \mathrm{ppm}$. At 18.087 Retention times the P-cumeric Acid was obtained which has value of $2.01 \mathrm{ppm}$. At 25.613 retention time the Cinamic acid was produced and value was $10.24 \mathrm{ppm}$.

\section{REFERENCES}

1. Yoshimura, R., Oshiman, N., Uyeshima, M., Ogawa, Y., Mishina, M., Toh, H., ... \& Miura, T. (2008). Magnetotelluric observations around the focal region of the 2007 Noto Hanto Earthquake (M j 6.9), Central Japan. Earth, planets and space, 60(2), 117-122.

2. Newman, R. K., \& Newman, C. W. (2008). For food and health: Science, technology, and products. John Wiley \& Sons USA.

3. Bergh, M. O., Razdan, A., \& Aman, P. (1999). Nutritional influence of broiler chicken diets based on covered normal, waxy and high amylose s with or without enzyme supplementation. Animal Feed Science and Technology, 78(3):215-226.

4. Baik, B. K., \& Ullrich, S. E. (2008). For food: characteristics, improvement, and renewed interest. Journal of Cereal Science, 48(2):233-242.

5. Kim, E. Y., Baik, I. H., Kim, J. H., Kim, S. R., \& Rhyu, M. R. (2004). Screening of the antioxidant activity of some medicinal plants. Korean Journal of Food Science and Technology, 36(2), 333-338.

6. Cheema, M. J. M., \& Bastiaanssen, W. G. (2010). Land use and land cover classification in the irrigated Indus Basin using growth phenology 
information from satellite data to support water management analysis. Agricultural water management, 97(10), 1541-1552.

7. Chavan, J. K., Kadam, S. S., \& Beuchat, L. R. (1989). Nutritional improvement of cereals by sprouting. Critical Reviews in Food Science \& Nutrition, 28(5):401-437.

8. Tudor, G., Darcy, T., Smith, P., \& Shallcross, F. (2003). The intake and live weight change of drought master steers fed hydroponically grown, young sprouted barley fodder (Auto Grass). Department of Agriculture Western Australia, 8.

9. Core, J. (2003). Study Investigates Health Benefits of. USDA: Agricultural Research Service, 29.

10. Lorenz, K., \& D'Appolonia, B. (1980). Cereal sprouts: composition, nutritive value, food applications. Critical Reviews in Food Science \& Nutrition, 13(4): 353-385.

11. Prasad, R., Sehgal, J. P., Patnayak, B. C., \& Beniwal, R. K. (1998).Utilization of artificially grown fodder by sheep. The Indian Journal of Small Ruminants, 4(2):63-68.

12. Gesgeshi, W., Ityopp'ya, W. I., Forward, M., \& Ethiopia, D. M. (2012). Semitaukecamatan.kpt. co. id LayananInformasi 17 Jam. Ethnic groups, 2:34-5.

13. Boyles, S. L., Anderson, V. L and Koch, K. B. (2001).Feeding to cattle. Beef Information, Ohio State University, http://beef. osu. Edu/library/. Html.

14. Sandoval, D. (2011). The green foods bible: Everything you need to know about grass, wheatgrass, kamut, chlorella, spirulina and more. SCB Distributors.
15. McGee, R. W. (2007). The ethics of tax evasion: A survey of Australian opinion. Available at SSRN 979410

16. Belitz, C., Brezger, A., Kneib, T., Lang, S., \& Umlauf, N. (2009). BayesX-Software for Bayesian inference in structured additive regression models. URL http://www. stat. uni-muenchen. de/ bayesx.

17. Amerine, M. A., Roessler, E. B., \& Ough, C. S. (1965). Acids and the acid taste. I. The effect of $\mathrm{pH}$ and titratable acidity. American Journal of Enology and Viticulture, 16(1):29-37.

18. AACC (American Association of Cereal Chemists). (2000). Approved methods of the AACC. St. Paul: AACC.

19. De Smedt, J. M. (1998). AOAC validation of qualitative and quantitative methods for microbiology in foods. International journal of food microbiology, 45(1), 25-28.

20. Steel, R. G., Torrie, J. H., \& Dickey, D. A. (1997) Principal and procedure of statistics: A biometrical approach. $3^{\text {rd }}$ edition McGraw Hill Book Co., New York USA.

21. Mahjoub, M. A., Monier, G., Robert-Goumet, C., Réveret, F., Echabaane, M., Chaudanson, D., \& Gruzza, B. (2016). Synthesis and study of stable and size-controlled $\mathrm{ZnO}-\mathrm{SiO} 2$ quantum dots: application as a humidity sensor. The Journal of Physical Chemistry C, 120(21):11652-11662.

22. Safdar, A., Wei, L. Y., Snis, A., \& Lai, Z. (2012). Evaluation of microstructural development in electron beam melted Ti-6Al-4V. Materials Characterization, 65:8-15. 